\title{
ВНЕШНЕСЕКРЕТОРНАЯ ФУНКЦИЯ ПОДЖЕЛУДОЧНОЙ ЖЕЛЕЗЫ КУР-НЕСУШЕК (Gallus gallus L.) ПРИ ДОБАВЛЕНИИ В КОРМ РАЗЛИЧНЫХ РАСТИТЕЛЬНЫХ МАСЕЛ*
}

\author{
В.Г. ВЕРТИПРАХОВ, А.А. ГРОЗИНА, В.И. ФИСИНИН
}

В практике птицеводства значительный интерес представляет вопрос об использовании растительных масел в питании птицы. Результаты многих исследований, полученные на цыплятахбройлерах, показывают, что добавка к корму разных растительных масел отражается на продуктивности и обменных процессах. Однако механизм влияния растительного масла на экзокринную функцию поджелудочной железы птицы до конца не изучен. В представляемой работе нами на фистулированной птице впервые получены данные, которые позволили проанализировать механизм воздействия различных липидных компонентов корма на секрецию панкреатического сока и его ферментативную активность, а также предложить индикатор (индекс активности щелочная фосфатаза/протеазы), который достоверно отражает физиологическое состояние пищеварительного канала птицы при адаптации к новому ингредиенту корма. Исследования выполняли на курахнесушках (Gallus gallus L.) кросса Hisex White $(n=3$, ФНЦ Всероссийский научно-исследовательский и технологический институт птицеводства РАН, 2019 год) с хронической фистулой панкреатического протока (по Батоеву, 2001). Физиологический опыт проводили методом периодов (по 7-10 сут): в контрольный период куры в качестве добавки к базовому комбикорму ПК-1 получали подсолнечное масло, в периоды опыта 1 - соевое, опыта 2 - рапсовое, опыта 3 - льняное. Измеряли количество панкреатического сока за опыт, активность его пищеварительных ферментов (амилаза, липаза, общие протеазы), щелочной фосфатазы определяли общепринятыми методами. Плазму крови исследовали на активность амилазы, липазы, аланинаминотрансферазы (АлАТ), аспартатаминотрансферазы (АсAT) на приборе Chem well 2900 (T) («Awareness Technology», США) с использованием соответствующих наборов реагентов («Нuman GmbH», Германия). Активность трипсина оценивали на полуавтоматическом биохимическом анализаторе Sinnowa BS3000P («SINNOWA Medical Science \& Technology Co., Ltd», KHP) с BAPNA в качестве субстрата. Биохимические показатели крови определяли на полуавтоматическом биохимическом анализаторе Sinnowa BS-3000Р с использованием наборов компании ДИАКОН-ВЕТ (Россия). Проведенные исследования показали, что активность липазы адаптируется к используемому в корме растительному маслу. Самую высокую активность $(21345 \pm 652,8$ мкмоль/(л м мин, р < 0,05) отмечали при введении в рацион подсолнечного нерафинированного масла, одновременно в панкреатическом соке усиливается амилолитическая активность $(9254 \pm 440,3$ мг/(мл • мин), р < 0,05). Анализ динамики активности панкреатической липазы в постпрандиальный период свидетельствует о том, что по вкусовым качествам лидируют подсолнечное и льняное масло, поскольку в первые минуты после приема корма наблюдается усиление ферментативной активности, соответствующее сложно-рефлекторной фазе регуляции панкреатической секреции. Рапсовое и соевое масла индуцируют высокую активность липазы в нейрогуморальную фазу, что указывает на их высокую питательную ценность. Установлена корреляция $(r=-0,87, \mathrm{p}<\mathbf{0 , 0 5})$ между активностью протеаз и щелочной фосфатазы в панкреатическом соке, что позволяет предложить использовать фосфатазно-протеазный индекс в качестве маркера физиологического состояния кишечника в ответ на изменения в ингредиентном составе рациона. Из биохимических показателей крови кур при изменении состава растительного масла в рационе наиболее лабильна активность трипсина, липазы, аминотрансфераз и концентрация триглицеридов в крови. Активность липазы крови при изменении липидного компонента в корме изменяется одновременно с активностыю фермента в панкреатическом соке, а фосфатазно-протеазный индекс при этом частично повторяет показатели, полученные при его определении в панкреатическом соке кур. Изменение секреторной функции поджелудочной железы при добавках различных растительных масел служит основанием для продолжения исследований процессов пищеварения с целью выявления оптимальных ингредиентов в кормлении птицы.

Ключевые слова: экзокринная функция поджелудочной железы, куры, пищеварительные ферменты крови, подсолнечное масло, соевое масло, рапсовое масло, льняное масло.

Вопросы, связанные с адаптацией пищеварительных желез животных к качеству рациона, до сих пор остаются дискуссионными и актуальными

\footnotetext{
* Работа выполнена при финансовой поддержке подпрограммы «Изучение механизмов адаптации системы пищеварения млекопитающих животных и птицы к рационам с различным ингредиентным составом кормов» в соответствии с Программой фундаментальных исследований РАН (постановление Президиума РАН № 132 от 05.07 .2017$)$.
} 
как для фундаментальных исследований, так и в практическом аспекте. В экспериментах на птицах установлено, что желудочная секреция и экзокринная функция поджелудочной железы адаптируются к химическому составу пищи $(1,2)$. В практике птицеводства значительный интерес представляет использовании растительных масел в кормлении. Опыты на бройлерах (3, 4) указывают на преимущество соевого, рыжикового, льняного масел по сравнению с подсолнечным. При замене подсолнечного масла на другие масла отмечается увеличение живой массы, снижение затрат корма на единицу продукции, повышение качества мяса и рентабельности. Существует точка зрения (5), что при использовании подсолнечного масла улучшается развитие птицы и конверсия корма по сравнению с тем, когда в рационе присутствует оливковое масло.

Установлено (6), что комбикорма с рапсовым маслом не уступали по эффективности таковым с подсолнечным маслом. Зарубежные авторы считают, что положительный эффект от применения рапсового масла в рационе выражается в увеличении содержания полиненасыщенных жирных кислот в мясе цыплят-бройлеров (7). Рапсовое масло как источник липидов превосходит пальмовое масло благодаря повышенной концентрации усваиваемых жирных кислот. В мясе кур, которых кормили рапсовым маслом, преобладала олеиновая кислота (8).

Известно (9), что существуют различия между липидными композициями в переваривании и всасывании различных жиров. Была показана корреляция между липидным профилем сыворотки крови и составом жирных кислот, поступающих с кормом и метаболизируемых в организме. Это позволило авторам предположить, что липидный состав рациона может модулировать состояние пищеварения и всасывания в желудочно-кишечном канале (9).

Сравнительные исследования на овцах показали, что рапсовое и льняное масла, добавляемые в рацион, влияют на активность ферментов поджелудочной железы. Секреция желчно-панкреатического сока имела тенденцию к увеличению у овец, получавших рапсовое и льняное масла (соответственно 69,5 и 68,5 мл/ч) по сравнению с контрольными животными (59,8 мл/ч), повышалась активность липазы и трипсина (соответственно 175 и 21,6 ед/л и 179 и 23,2 ед/л) по сравнению с контрольным рационом (соответственно 128 и 13,1 ед/л) (10).

Таким образом, сведения о влиянии разных растительных масел на продуктивность птицы неоднозначны, а информация о механизмах действия этих нутриентов на пищеварительную систему отсутствует.

В представленном сообщении впервые показано, что в сравнении с использованием соевого, рапсового или льняного масла при добавлении в рационе кур подсолнечного нерафинированного масла значительно усиливается липолитическая и амилолитическая активность панкреатического сока, изменяется фосфатазно-протеазный индекс, а также биохимический профиль плазмы крови, который согласуется с показателями секреторной функции поджелудочной железы.

Цель работы - изучить влияние различных растительных масел на секреторную функцию поджелудочной железы и биохимические показатели крови у кур-несушек.

Методика. Исследования выполняли на трех курах (Gallus gallus domesticus L.) породы Хайсекс белый (Hisex White) 28-46-недельного возраста, прооперированных по методу Ц.Ж. Батоева и С.Ц. Батоевой $(2,11)$. Из 12-перстной кишки выкраивали отрезок длиной 4-5 см, в который трансплантировали главный панкреатический проток с вживлением двух Г- 
образных фистул. В результате формировали внешний анастомоз, позволяющий возвращать панкреатический сок в 12-перстную кишку в периоды между опытами. Кур содержали в виварии (ФНЦ ВНИТИП РАН, 2019 год) с соблюдением условий кормления и содержания, оптимальных для этого кросса (12). Физиологический опыт начинали утром натощак после 14-16часового голодания птиц. Кур помещали в специальный станок, в котором они находились в течение 3 ч. К фистуле из изолированного отрезка прикрепляли с помощью специального резинового переходника микропробирку для сбора панкреатического сока. В первые 30 мин собирали сок после голодания, затем птицам давали 30 г комбикорма и продолжали собирать секрет через каждые 30 мин. Варианты опыта: базовый корм согласно нормам для кросса (БК, комбикорм ПК-1, Россия) (12) + 2,6 \% соевого масла (опыт 1), БК + 2,6 \% рапсового масла (опыт 2) и БК + 2,6 \% льняного масла (опыт 3); контроль - БК + 2,6 \% подсолнечного масла. Опыты выполняли методом периодов: контрольный период (7-10 сут), переходный период (2-3 сут), опытный период (7-10 сут). Каждую серию опытов повторяли не менее трех раз.

Активность амилазы в образцах секрета определяли по Smith-Roe в модификации для высоких значений показателя (2), протеаз - по гидролизу казеина очищенного по Гаммерстену при колориметрическом контроле $(\lambda=450$ нм) $(2)$, липазы - на полуавтоматическом биохимическом анализаторе Sinnowa BS3000P («SINNOWA Medical Science \& Technology Co., Ltd», Китай) с набором ветеринарных диагностических реагентов для определения концентрации липазы в крови животных («ДИАКОН-ВЕТ», Россия).

Кровь для исследования (2-3 мл) брали натощак (после 14-часового голодания птиц) из подкрыльцовой вены, добавляли цитрат натрия в качестве антикоагулянта, центрифугировали при 5000 об/мин в течение 5 мин.

В полученной плазме крови измеряли активность пищеварительных ферментов - трипсина, амилазы и липазы. В качестве субстрата для трипсина использовали N $\alpha$-бензоил-DL-аргинин-п-нитроанилид (BAPNA, «ACROS ORGANICS», Швейцария), активность определяли на полуавтоматическом биохимическом анализаторе Sinnowa BS3000P (KHР) кинетическим методом (13). Для определения активности амилазы и липазы в плазме крови использовали биохимический автоматическом анализаторе Chem well 2900 (T) (США) с наборов реагентов («Human $\mathrm{GmbH»,} \mathrm{Германия).}$

Для статистической обработки результатов использовали программное обеспечение JMP Trial 14.1.0 (https://www.jmp.com/en_us/home.html), выполняли расчет средних значений $(M)$ и среднеквадратичных отклонений $( \pm \mathrm{SD})$, коэффициентов корреляции Пирсона $(r)$. Достоверность различий устанавливали по $t$-критерию Стьюдента, различия считали статистически значимыми при $\mathrm{p}<0,05$.

Результаты. Углубленное изучение экзокринной функции поджелудочной железы связывают с методами экспериментальной хирургии, разработанными академиком И.П. Павловым (14). В 1904 году И.П. Павлов был удостоен Нобелевской премии за «работу по физиологии пищеварения», в которой он предложил использовать в эксперименте изолированную часть желудка (желудочек), сохраняющего ту же иннервацию, что и основной желудок. Этот прием позволил изучать физиологические явления на объектах, находящихся в состоянии нормы. Еще одно открытие И.П. Павлова - хронические опыты с животными, подготовленными хирургическими метода- 
ми, что позволили отказаться от острых опытов, к концу которых, как правило, животные погибали.

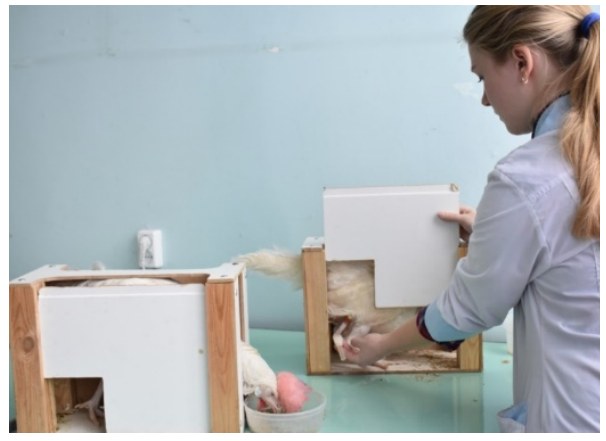

Рис. 1. Куры (Gallus gallus domesticus L.) породы Hisex White с хронической фистулой панкреатического протока: эксперимент по изучению влияния разных растительных масел на процессы пищеварения (виварий ФНЦ ВНИТИП РАН, 2019 год).
Мы использовали кур с хронической фистулой панкреатического протока (2), от которых получали секрет в течение опыта (180 мин), а в остальное время, соединив канюли резиновым переходником, направлять его в кишечник (рис. 1). Такой метод, на наш взгляд, лучше всего подходит для изучения влияния разных растительных масел на процессы пищеварения, поскольку поджелудочная железа очень чувствительна к составу рациона, а тот факт, что исследование выполняется на живом и здоровом организме позволяет наиболее полно проследить адаптацию к новому ингреди-

енту рациона и проанализировать ее механизм.

Одна из проблем современного птицеводства - необходимость замены некоторых ингредиентов рациона более дешевыми компонентами, однако об их действии на организм птицы часто известно мало, а для некоторых потенциальных добавок оно совсем не изучено. Наряду с источниками белка (15), к таким компонентам относятся растительные масла.

Мы сравнили влияние подсолнечного, соевого, рапсового и льняного нерафинированных масел на экзокринную функцию поджелудочной железы кур. Полученные результаты показывают, что экзокринная функция кур-несушек адаптируется к каждому из добавленных растительных масел (табл. 1).

1. Экзокринная функция поджелудочной железы у кур-несушек (Gallus gallus domesticus L.) породы Hisex White при добавлении в базовый рацион (БР) разных растительных масел ( $M \pm \mathrm{SD}, n=9$, виварий ФНЦ ВНИТИП РАН, 2019 год)

\begin{tabular}{|c|c|c|c|c|}
\hline Показатель & Контроль & Опыт 1 & Опыт 2 & Опыт 3 \\
\hline \multicolumn{5}{|l|}{ Количество панкреатического } \\
\hline \multicolumn{5}{|c|}{ Активность в расчете на 1 мл панкреатического сока: } \\
\hline амилаза, мг/(мл • мин) & $9254 \pm 440,3$ & $6531 \pm 381,4^{*}$ & $6014 \pm 467,7^{*}$ & $7685 \pm 376,8^{*}$ \\
\hline липаза, мкмоль/(л· мин) & $21345 \pm 652,8$ & $12347 \pm 594,8^{*}$ & $9048 \pm 486,4^{*}$ & $17264 \pm 1000,2^{*}$ \\
\hline протеазы, мг/(мл· мин) & $391 \pm 16,0$ & $400 \pm 14,2$ & $401 \pm 18,4$ & $415 \pm 23,5$ \\
\hline \multicolumn{5}{|c|}{ Суммарная активность за 180 мин опыта: } \\
\hline амилаза, мг/(мл· мин) & $34878 \pm 2347,3$ & $26210 \pm 1882,9^{*}$ & $23652 \pm 2424,2^{*}$ & $25847 \pm 1221,4^{*}$ \\
\hline ь/(л • мин) & $78435 \pm 6174,7$ & $49959 \pm 2787,3^{*}$ & $32370 \pm 2956,5^{*}$ & $58148 \pm 2882,9^{*}$ \\
\hline протеазы, мг/(мл·мин) & $1475 \pm 79,8$ & $1528 \pm 62,8$ & $1386 \pm 49,3$ & $1354 \pm 69,8$ \\
\hline трипсин, ед/л & $5709 \pm 233,6$ & $5840 \pm 204,4$ & $5855 \pm 268,6$ & $6059 \pm 343,1$ \\
\hline щелочная фосфатаза, ед/л & $5707 \pm 321,5$ & $12159 \pm 566,0^{*}$ & $3961 \pm 188,1^{*}$ & $10791 \pm 423,6^{*}$ \\
\hline Индекс ЩФ/протеазы & 1,0 & 2,1 & 0,7 & 1,8 \\
\hline
\end{tabular}

П р и м е ч а н и е. Контроль - БР $+2,6 \%$ подсолнечного масла, опыт $1-$ БР $+2,6 \%$ соевого масла, опыт $2-$ БР $+2,6 \%$ рапсового масла, опыт $3-$ БК $+2,6 \%$ льняного масла; ЩФ щелочная фосфатаза.

* Различия между контрольным и опытными периодами статистически значимы при р $<0,05$.

Представленные в таблице 1 данные показывают, что при использовании в рационе кур-несушек разных растительных масел количество панкреатического сока за опыт существенно не изменяется. Наибольшая липолитическая активность отмечается в контрольный период при использовании подсолнечного масла. При его замене на соевое масло активность 
липазы уменышается на 42,2 \% ( $<<0,05)$. Рапсовое масло снижает активность липазы на 57,6 \% по сравнению с контролем (p < 0,05), льняное на $19,1 \%$ ( $<0,05)$. Следовательно, происходит адаптация активности липазы к используемому в корме растительному маслу. Активность амилазы также изменяется в зависимости от вида масла, но наибольшую активность отмечается в варианте с подсолнечным маслом. При использовании соевого масла амилолитическая активность на 1 мл панкреатического сока снижается на $31,6 \%$ относительно таковой в контрольный период $(\mathrm{p}<0,05)$, рапсового масла - на 35,1\% (p < 0,05), льняного - на 17,0 \% (p < 0,05). При добавлении в корм определенного масла активность амилазы и липазы изменяется синхронно. Самый низкий показатель активности амилазы и липазы отмечается при добавке рапсового масла, далее с последовательным увеличением ранжируется соевое, льняное и подсолнечное. Однозначного ответа на вопрос, почему рапсовое масло имеет столь низкую стимулирующую активность в отношении панкреатических ферментов, пока нет, но, по-видимому, это связано с наличием большого числа ненасыщенных жирных кислот (табл. 2), которые представлены в основном олеиновой кислотой. Для рапсового масла количественное соотношение суммы ненасыщенных и полиненасыщенных жирных кислот к насыщенным составляет 11:1, для подсолнечного масла - 8:1, соевого - 5:1, льняного - 9:1 (см. табл. 2).

2. Жирнокислотный состав растительных масел, использованных в эксперименте (виварий ФНЦ ВНИТИП РАН, 2019 год)

\begin{tabular}{|c|c|c|c|c|}
\hline Жирная кислота & Подсолнечное & Coевое & Рапсовое & Льняное \\
\hline Масляная & 0,01 & 0,01 & 0,01 & 0,01 \\
\hline Каприловая & 0,02 & - & - & - \\
\hline Каприновая & - & - & 0,01 & - \\
\hline Лауриновая & - & - & 0,01 & - \\
\hline Тридекановая & - & 0,02 & - & - \\
\hline Миристиновая & 0,06 & 0,06 & 0,05 & 0,03 \\
\hline Пентадекановая & 0,03 & 0,03 & 0,04 & 0,04 \\
\hline Пальмитиновая & 6,24 & 11,14 & 4,73 & 5,68 \\
\hline Пальмитолеиновая & 0,08 & 0,09 & 0,10 & 0,02 \\
\hline Гептадекановая (маргариновая) & 0,03 & 0,07 & 0,04 & 0,05 \\
\hline Маргаролевая & 0,02 & 0,05 & 0,05 & 0,03 \\
\hline Стеариновая & 3,70 & 3,90 & 2,13 & 4,14 \\
\hline Олеиновая & 31,06 & 29,41 & 66,50 & 14,44 \\
\hline Элаидиновая & 0,61 & 1,03 & - & - \\
\hline Линолевая & 56,81 & 47,79 & 17,62 & 16,99 \\
\hline$\alpha$-Линоленовая & 0,04 & 5,08 & 6,57 & 58,14 \\
\hline Арахиновая & 0,26 & 0,45 & 0,62 & 0,15 \\
\hline Эйкозеновая (гондоиновая) & 0,20 & 0,34 & 1,00 & 0,06 \\
\hline Эйкозоеновая & - & 0,03 & 0,08 & 0,03 \\
\hline Арахидоновая & - & - & - & 0,04 \\
\hline Бегеновая & 0,65 & 0,38 & 0,29 & 0,08 \\
\hline Тетракозановая (лигноцериновая) & 0,20 & 0,13 & 0,09 & 0,07 \\
\hline Нервоновая & - & - & 0,06 & - \\
\hline Сумма насыщенных жирных кислот & 11,18 & 16,21 & 8,10 & 10,28 \\
\hline Сумма ненасыщенных жирных кислот & 31,97 & 30,92 & 67,71 & 14,55 \\
\hline \multicolumn{5}{|c|}{ Сумма полиненасыщенных жирных кислот: } \\
\hline всего & 56,85 & 52,87 & 24,19 & 75,17 \\
\hline$\omega-3$ & 0,04 & 5,08 & 6,57 & 58,14 \\
\hline$\omega-6$ & 56,81 & 47,79 & 17,62 & 17,03 \\
\hline
\end{tabular}

При м еч а и е. Исследования выполнены по ГОСТ 30418 «асла растительные. Метод определения жирнокислотного состава» в Испытательном лабораторном центре ВНИИПП (Ржавки, Московская обл.). Указана величина пиков кислоты как процент от суммарной площади пиков всех жирных кислот. Прочерки означают отсутствие соответствующей жирной кислоты.

Эксперименты показали, что протеолитическая активность сока поджелудочной железы при замене в рационе растительного масла существенно не изменяется. Активность щелочной фосфатазы адаптируется к различным маслам, вследствие этого фосфатазно-протеазное соотношение (индекс ЩФ/протеазы) увеличивается в 2,1 раза при замене подсолнечного 
масла на соевое, в 1,8 раза - на льняное. При использовании рапсового масла индекс приближается к таковому в контрольный периоду и составляет 0,7. Основанием для расчетов индекса ЩФ/протеазы послужили результаты исследования корреляции между данными показателями, которые обнаружили обратную сильную связь $(r=-0,87 ; \mathrm{p}<0,05)(16)$.

Результаты исследования химического состава масел согласуются с данными литературы, где указано, что по содержанию олеиновой кислоты рапсовое масло имеет самый высокий показатель среди жирных кислот (17). Известно (18), что на отложение жира в организме бройлеров влияет соотношение $\omega-6$ и $\omega-3$ кислот. Их оптимальное соотношение характерно для рапсового масла - 3:1, у подсолнечного этот показатель очень высокий 1420:1, у соевого - 9:1, тогда как льняное масло, наоборот, содержит 5кратный избыток $\omega-3$ кислот относительно $\omega-6$ кислот.

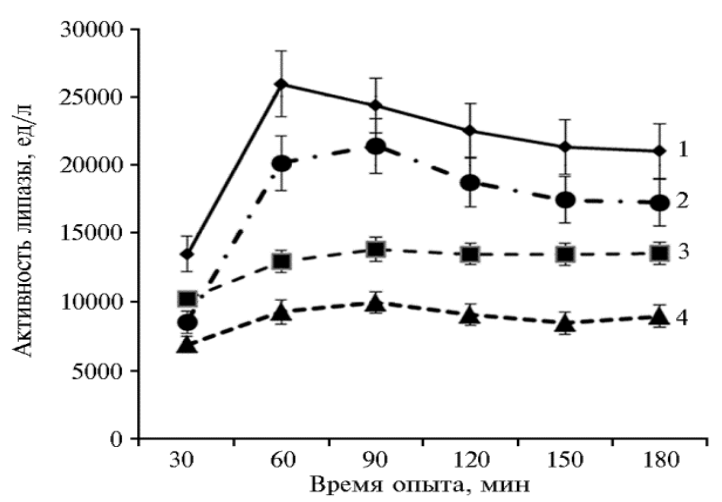

Рис. 2. Динамика активности липазы у кур-несушек (Gallus gallus domesticus L.) породы Hisex White при добавлении в базовый рацион (БР) разных растительных масел: 1 - подсолнечное, 2 - льняное, 3 - соевое, 4 - рапсовое; базальный уровень - показатель на 30-й мин (до кормления) ( $M \pm \mathrm{SD}, n=9$, виварий ФНЦ ВНИТИП РАН, 2019 год). прандиальную фазу в течение 60 мин, и далее активность остается примерно на одном уровне до конца опыта (180 мин). Аналогично выглядит кривая, отражающая динамику активности липазы при использовании в корме соевого масла. Возможно, такая реакция внешнесекреторной функции поджелудочной железы обусловлена тем, что в пищеварительном канале масло находится в состоянии эмульсии, поскольку у уток, например, установлено положительное влияние типа жира и эмульгаторов на липидный обмен (19).

В отличие от предыдущих графиков, при использовании льняного масла кривая динамики липазной активности характеризуется резким повышением в сложнорефлекторную фазу регуляции функции панкреаса: активность фермента в первые 60 мин после приема корма увеличивается в 2,5 раза, снижаясь в дальнейшем в нейрохимическую фазу в 1,2 раза относительно максимума. Наблюдаемый эффект, по-видимому, связан с тем, что льняное масло имеет горький вкус и по запаху похоже на рыбий жир (рыбную муку), что вызывает рефлекторный ответ со стороны пищевого центра на импульсы, приходящие от рецепторов ротовой полости, и способствует повышению аппетита. Через 60 мин после кормления, когда содержимое желудка поступает небольшими порциями в кишечник, происходит более детальная оценка качества питательных веществ, и дуоденум реагирует выделением гормонов (секретин, холецистокинин) более сдержанно, 
чем рецепторы ротовой полости.

Кривая выделения липазы в ответ на потребление подсолнечного масла имеет резкий подъем в первые 30 мин постпрандиальной фазы, когда активность фермента увеличивается в 1,9 раза по сравнению с базальной $(\mathrm{p}<0,05)$. В дальнейшем наблюдается спад активности липазы, обусловленный, по-видимому, наличием ингибитора липазы в подсолнечном масле (20) и отсутствием стимулирующего эффекта при нейрохимической регуляции панкреатической секреции.

Биохимические показатели крови животных отражают состояние обменных процессов в организме (21), поэтому трудно представить, чтобы изменения в экзокринной функции поджелудочной железы кур-несушек не повлияли на показатели крови (табл. 3).

3. Биохимические показатели крови у кур-несушек (Gallus gallus domesticus L.) породы Hisex White при добавлении в базовый рацион разных растительных масел $(M \pm \mathrm{SD}, n=10$; виварий ФНЦ ВНИТИП РАН, 2019 год)

\begin{tabular}{|c|c|c|c|c|}
\hline \multirow{2}{*}{ Показатель } & \multicolumn{4}{|c|}{ Базовый рацион с содержанием 2,6 \% масла } \\
\hline & подсолнечного & соевого & рапсового & льняного \\
\hline Трипсин, ед/л & $89 \pm 11,3$ & $164 \pm 20,3^{*}$ & $167 \pm 11,5^{*}$ & $84 \pm 7,0$ \\
\hline Амилаза, ед/л & $336 \pm 51,3$ & $319 \pm 29,5$ & $341 \pm 30,1$ & $394 \pm 27,6$ \\
\hline Липаза, ед/л & $43 \pm 2,3$ & $25 \pm 1,1 *$ & $22 \pm 1,4^{*}$ & $37 \pm 2,0$ \\
\hline АлАТ, ед/л & $18 \pm 5,3$ & $8 \pm 0,9^{*}$ & $7 \pm 0,9^{*}$ & $5 \pm 0,9 *$ \\
\hline АсАТ, ед/л & $129 \pm 6,0$ & $153 \pm 7,2 *$ & $140 \pm 9,2$ & $145 \pm 14,1$ \\
\hline Коэффициент де Ритиса & 7,2 & 19,1 & 20,0 & 29,0 \\
\hline Общий белок, г/л & $35 \pm 1,3$ & $40 \pm 1,9$ & $39 \pm 1,3$ & $34 \pm 0,7$ \\
\hline Триглицериды, ммоль/л & $2,3 \pm 0,30$ & $5,3 \pm 0,64^{*}$ & $4,9 \pm 0,36^{*}$ & $2,8 \pm 0,17$ \\
\hline Холестерин, ммоль/л & $1,9 \pm 0,16$ & $2,4 \pm 0,21$ & $2,2 \pm 0,22$ & $2,2 \pm 0,16$ \\
\hline Щелочная фосфатаза, ед/л & $2056 \pm 253,5$ & $3040 \pm 439,5$ & $2514 \pm 638,5$ & $2701 \pm 178,1$ \\
\hline Индекс ЩФ/трипсин & 23,1 & 18,5 & 15,0 & 32,1 \\
\hline
\end{tabular}

П р и м е ч а и е. АлАТ - аланинаминотрансфераза, АсАТ - аспартатаминотрансфераза, ЩФ - щелочная фосфатаза.

* Различия между контрольным и опытными периодами статистически значимы при р < 0,05 .

Самую высокую активность трипсина в плазме крови отмечали в случае соевого и рапсового масла: показатели превышали контроль (подсолнечное масло) соответственно на 84,3 и 87,6 \% (p < 0,05). Активность трипсина при добавлении в корм льняного масла соответствовала контролю (вариант с подсолнечным маслом). Нужно отметить, что активность трипсина при использовании соевого и рапсового масла находится на верхней границе физиологической нормы для кур-несушек (13), что может быть связано с наличием антипитательных факторов (ингибитора трипсина) в этих маслах (20). По активности амилазы в плазме крови кур мы не отмечали существенных различий. Активность липазы в крови самая высокая у кур, получавших добавку подсолнечного масла, что согласуется с состоянием экзокринной функции поджелудочной железы в ответ на потребление подсолнечного масла. При добавлении соевого масла в рацион кур активность липазы снижалась на 41,9 \% (p < 0,05), рапсового - на 48,8\% (p < 0,05), льняного - на 14,0 ( $<<0,05)$. Следовательно, изменение активности липазы в плазме крови следует динамике активности фермента в панкреатическом соке. Сопряженную модуляцию активности дуоденальной липазы и липазы в крови наблюдали при добавлении в рацион бройлеров препарата желчных кислот, что согласуется с нашими экспериментальными данными (22). Анализ активности аминотрансфераз свидетельствует, что эти показатели также зависят от липидного компонента корма (см. табл. 3). Наиболее критичный рост величины коэффициента де Ритиса, характеризующего отношение активности аспартатаминотрансферазы к активности аланинаминотрансферазы, отмечали при добавлении в корм льняного масла. 
Активности щелочной фосфатазы в крови кур существенно не различалась в разные периоды, хотя отмечалась тенденция увеличения этого показателя при использовании соевого масла. Рост активности щелочной фосфатазы происходит в результате общесистемной реакции организма, что сопровождается нарушением процессов окислительного фосфорилирования в органах и тканях и изменением проницаемости клеточных мембран (23).

При использовании соевого и рапсового масел заметно возрастала концентрация триглицеридов в крови, что указывает на высокую доступность этих жиров для организма кур-несушек. Так, при использовании соевого масла количество липидов в крови увеличивается на $130,0 \%$, а рапсового - на 113,0 \% по сравнению с показателем для подсолнечного масла. У птицы лимфатическая система практически не развита, поэтому всасывание жиров происходит через систему воротной вены печени. Характерно, что во время абсорбции и транспортировки жира не происходит изменения в его жирнокислотном составе. Поэтому существует большое сходство между жиром, который скармливают птице, и жиром, депонируемым в организме. Необходимо учитывать, что триглицериды могут синтезироваться из глюкозы в процессе усвоения углеводов. Таким образом, окончательный состав жира в теле птицы будет складываться из жиров корма, эндогенных жиров из глюкозы и жиров, полученных в результате бета-окисления высших жирных кислот (когда ненасыщенные кислоты восстанавливаются до насыщенных) (24).

Индекс щелочная фосфатаза/протеазы (трипсин) (см. табл. 3) согласуется с показателями, характеризующими экзокринную функции поджелудочной железы (см. табл. 1) в том, что самый низкий индекс отмечали при использовании рапсового масла. Данные о взаимосвязи активности щелочной фосфатазы в кишечнике и крови были получены при изменении компонентов в составе рациона цыплят-бройлеров (25). Наши опыты показали, что наиболее эффективное усвоение протеина корма происходит при добавлении рапсового масла благодаря оптимизации функции пищеварительных желез (поджелудочной железы и печени). Представленные нами результаты также подтверждают «нагруженный» метаболизм печени и поджелудочной железы при использовании льняного масла (в этом случае происходило повышение индекса ЩФ/трипсин до 32,1). Следовательно, соотношение ЩФ и протеаз имеет диагностическое значение и может служить индикатором физиологического состояния пищеварительного канала.

Таким образом, наши исследования показали, что различные липидные компоненты рациона влияют на обмен веществ у кур-несушек через изменение функции поджелудочной железы и состояние желудочно-кишечного канала. В научной литературе имеются данные о воздействии жиров на метаболизм глюкозы и липидов у свиней (26), об изменении микробиоты кишечника при замене жиров в рационе овец (27), улучшении пищеварения, руминального брожения и жирнокислотного профиля рубца у молочных коров под влиянием льняного масла (28). Установлено, что растительные масла, богатые полиненасыщенными жирными кислотами, при добавлении в рационы молочных коров улучшают продуктивные и воспроизводительные показатели (29), отмечен положительный эффект рапсового масла при заболеваниях поджелудочной железы (уменьшение воспаления и снижение окислительного стресса) (30). Имеются ведения об увеличении объема секретов поджелудочной железы и желчи и повышении их липолитической и трипсиновой активности при добавлении в рацион овец рапсового и льняного масел (10). Однако мы не обнаружили сведений о влиянии 
разных растительных масел на секреторную функцию поджелудочной железы у птиц. Результаты, полученные на сложно прооперированных курах, впервые позволяют расшифровать механизм воздействия различных липидных компонентов корма на секрецию панкреатического сока и его ферментативную активность, определить индикатор (индекс щелочная фосфатаза/протеазы), который достоверно отражает физиологическое состояние пищеварительного канала птицы при адаптации к новому ингредиенту корма. Кроме того, проведенные эксперименты дают возможность сопоставить данные панкреатической секреции с биохимическими показателями крови кур при добавлении в корм одного из растительных масел, в результате чего нами установлено, что изменение активности липазы в плазме крови происходит аналогично активности фермента в панкреатическом соке.

Полученные нами данные дополняют информации о том, что ароматические соединения рапсового масла влияют на вкус пищевых продуктов (31). В целом результаты выполненного исследования согласуются с представлениями о том, что качество животноводческой продукции зависит от растительного масла, использованного в рационах. Так, подсолнечное масло улучшает жирнокислотный профиль молока и его окислительную стабильность у молочных коров (32), а в аквакультуре добавление сои и льняного семени с различным соотношением $\omega 6-\omega 3$ жирных кислот влияет на ростовые показатели, состав тканей, биосинтез жирных кислот и экспрессию липидных генов у атлантического лосося (Salmo salar) (33). У курнесушек размеры и качество яиц, а также биохимические показатели крови зависели от того, какое масло (рыбий жир, кокосовое и соевое масло) было включено в состав рациона (34), что связано с пищеварительной функцией поджелудочной железы.

Итак, выполненные эксперименты позволяют сделать следующие выводы. У кур-несушек активность липазы адаптируется к используемому в корме растительному маслу, причем в случае подсолнечного нерафинированного масла активность самая высокая. Активность амилазы также изменяется при использовании различных масел, и наибольшая также наблюдается для подсолнечного масла. Анализ динамики активности панкреатической липазы в постпрандиальный период свидетельствует о том, что по вкусовым качествам лидируют подсолнечное и льняное масла, поскольку в первые 60 мин после приема корма (период, соответствующий сложно-рефлекторной фазе регуляции панкреатической секреции) ферментативная активность повышается в 1,9-2,5 раза по сравнению с базальным уровнем, тогда как рапсовое и соевое масла заметно повышают активность липазы в нейро-гуморальную фазу, что указывает на их высокую питательную ценность. Активность трипсина, липазы, аминотрансфераз и содержание триглицеридов - наиболее лабильные биохимические показатели крови при замене растительного масла в рационе. Активность липазы в крови при смене липидного компонента в корме следовала за показателем для фермента в панкреатическом соке, а фосфатазно-протеазный индекс частично повторял показатели в панкреатическом соке. Установлена взаимосвязь между активностью протеаз и щелочной фосфатазы в панкреатическом соке и плазме крови, что позволяет предложить фосфатазно-протеазный индекс, который можно рассчитывать по показателям крови, для оценки физиологического состояния кишечника в ответ на изменения в ингредиентном составе рациона. Изменение секреторной функции подже- 
лудочной железы при добавках различных растительных масел служит основанием для продолжения исследований процессов пищеварения для выявления оптимальных ингредиентов в кормлении птицы.

\section{ЛИТЕРАТУРА}

1. Перепелкина Л.И., Бердников П.П., Самсоненко И.А. Физиологическая адаптация поджелудочной железы мускусных уток к абиотическим для вида составам рациона. Вестник Алтайского аграрного университета, 2012, 7(93): 67-68.

2. Батоев Ц.Ж. Физиология пищеварения птиц. Улан-Удэ, 2001.

3. Селина Т.В. Использование растительных масел в кормлении цыплят-бройлеров. Птицеводство, 2015, 7: 43-46.

4. Мальцева Н.А., Ядрищенская О.А., Селина Т.В. Использование рапсового масла в кормлении цыплят-бройлеров. Птицеводство, 2016, 7: 11-13.

5. Ваіго N.C., Lara L.J.C. Oil and fat in broiler nutrition. Brazilian Journal of Poultry Science, 2005, 7(3): 129-141 (doi: 10.1590/S1516-635X2005000300001).

6. Гаганов А.П., Зверкова 3.Н., Осипян Б.А. Высококонцентрированный источник энергии для бройлеров. Адаптивное кормопроизводство, 2019, 4: 36-47 (doi: 10.33814/AFP-22225366-2019-4-36-47).

7. Abbasi M.A., Ghazanfari S., Sharifi S.D., Ahmadi Gavlighi H. Influence of dietary plant fats and antioxidant supplementations on performance, apparent metabolizable energy and protein digestibility, lipid oxidation and fatty acid composition of meat in broiler chicken. Veterinary Medicine and Science, 2020, 6(1): 54-68 (doi: 10.1002/vms3.212).

8. Skřivan M., Marounek M., Englmaierová M., Čermák L., Vlčková J., Skřivanová E. Effect of dietary fat type on intestinal digestibility of fatty acids, fatty acid profiles of breast meat and abdominal fat, and mRNA expression of lipid-related genes in broiler chickens. PLoS ONE, 2018, 13(4): e0196035 (doi: 10.1371/journal.pone.0196035).

9. Ye Z., Cao C., Li R., Cao P., Li Q., Liu Y. Lipid composition modulates the intestine digestion rate and serum lipid status of different edible oils: a combination of in vitro and in vivo studies. Food \& Function, 2019, 10(3): 1490-1503 (doi: 10.1039/C8FO01290C).

10. Kowalik B., Majewska M.P., Miltko R., Bełżecki G. The effect of supplementing sheep with rapeseed and linseed oils on the activity of pancreatic digestive enzymes. Journal of Animal Physiology and Animal Nutrition, 2018, 102(5): 1194-1198 (doi: 10.1111/jpn.12936).

11. Vertiprakhov V.G., Egorov I.A. The influence of feed intake and conditioned reflex on exocrine pancreatic function in broiler chicks. Open Journal of Animal Sciences, 2016, 6(4): 298-303 (doi: 10.4236/Ojas.2016.64034).

12. Руководство по оптимизации рецептов комбикормов для сельскохозяйственной птицы /Под ред. В.И. Фисинина. Сергиев Посад, 2014: 3-4.

13. Вертипрахов В.Г., Грозина А.А. Оценка состояния поджелудочной железы методом определения активности трипсина в крови птицы. Ветеринария, 2018, 12: 51-54 (doi: 10.30896/00424846.2018.21.12.51-54).

14. Алиев А.А. Достижения физиологии пищеварения сельскохозяйственных животных в XX веке. Сельскохозяйственная биология, 2007, 2: 12-23.

15. Фисинин В.И., Вертипрахов В.Г., Грозина А.А. Внешнесекреторная функция поджелудочной железы кур (Gallus gallus L.) в зависимости от ингредиентов рациона. Сельскохозяйственная биология, 2018, 53(4): 811-819 (doi: 10.15389/agrobiology.2018.4.811rus).

16. Вертипрахов В.Г., Кислова И.В. Экзокринная функция поджелудочной железы кур-несушек при изменении уровня кальция в рационе. Международный вестник ветеринарии, 2019, 4: 118-124.

17. Konuskan D.B., Arslan M., Oksuz A. Physicochemical properties of cold pressed sunflower, peanut, rapeseed, mustard and olive oils grown in the Eastern Mediterranean region. Saudi Journal Biological Sciences, 2019, 26(2): 340-344 (doi: 10.1016/j.sjbs.2018.04.005).

18. Архипов А.В. Липидное питание, продуктивность птицы и качество продуктов птицеводства. M., 2007.

19. Hu X.Q., Wang W.B., Liu L., Wang C., Feng W., Luo Q.P., Han R., Wang X.D. Effects of fat type and emulsifier in feed on growth performance, slaughter traits, and lipid metabolism of Cherry Valley ducks. Poultry Science, 2019, 98(11): 5759-5766 (doi: 10.3382/ps/pez369).

20. Андрианова Е.Н., Егоров И.А., Присяжная Л.М., Григорьева Е.Н., Ребракова Т.М. Нужно ли учитывать содержание хлорогеновой кислоты в подсолнечнике при оценке качества продуктов его переработки? Птица и птицепродукты, 2016, 2: 39-41.

21. Метревели Т.В. Биохимия животных /Под ред. Н.С. Шевелева. СПб, 2005.

22. Lai W., Huang W., Dong B., Cao A., Zhang W., Li J., Wu H., Zhang L. Effects of dietary supplemental bile acids on performance, carcass characteristics, serum lipid metabolites and 
intestinal enzyme activities of broiler chickens. Poultry Science, 2018, 97(1): 196-202 (doi: $10.3382 / \mathrm{ps} / \mathrm{pex} 2880)$.

23. Клетикова Л.В. Динамика обмена кальция и фосфора у высокопродуктивных кур в зависимости от периода яйцекладки. Международный журнал прикладных и фундаментальных исследований, 2014, 1: 57-58.

24. Лазарева Н.Ю. Жиры в кормлении бройлеров. Птицеводство, 2019, 2: 37-40.

25. Barshan S., Khalaji S., Hedayati M., Yari M. Influence of bone meal degelatinisation and calcium source and particle size on broiler performance, bone characteristics and digestive and plasma alkaline phosphatase activity. British Poultry Science, 2019, 60(3): 297-308 (doi: 10.1080/00071668.2019.1587151).

26. Gu Z., Mu H., Shen H., Deng K., Liu D., Yang M., Zhang Y., Zhang W., Mai K. High level of dietary soybean oil affects the glucose and lipid metabolism in large yellow croaker Larimichthys crocea through the insulin-mediated PI3K/AKT signaling pathway. Comparative Biochemistry and Physiology Part B: Biochemistry and Molecular Biology, 2019, 231: 34-41 (doi: 10.1016/j.cbpb.2018.12.003).

27. Muralidharan J., Galiè S., Hernández-Alonso P., Bully M., Salas-Salvady J. Plant-based fat, dietary patterns rich in vegetable fat and gut microbiota modulation. Frontiers in Nutrition, 2019, 6: 157 (doi: 10.3389/fnut.2019.00157).

28. Pi Y., Ma L., Pierce K.M., Wang H.R., Xu J.C., Bu D.P. Rubber seed oil and flaxseed oil supplementation alter digestion, ruminal fermentation and rumen fatty acid profile of dairy cows. Animal, 2019, 13(12): 2811-2820 (doi: 10.1017/S175173111900137X).

29. Castro T., Martinez D., Isabel B., Cabezas A., Jimeno V. Vegetable oils rich in polyunsaturated fatty acids supplementation of dairy cows' diets: effects on productive and reproductive performance. Animals (Basel), 2019, 9(5): 2-16 (doi: 10.3390/ani9050205).

30. Atefi M., Pishdad G.R., Faghih S. The effects of canola and olive oils on insulin resistance, inflammation and oxidative stress in women with type 2 diabetes: a randomized and controlled trial. Journal of Diabetes \& Metabolic Disorders, 2018, 17(2): 85-91 (doi: 10.1007/s40200-0180343-9).

31. Zhou Q., Jia X., Yao Y.Z., Wang B., Wei C.Q., Zhang M., Huang F. Characterization of the aroma-active compounds in commercial fragrant rapeseed oils via monolithic material sorptive extraction. Journal of Agricultural and Food Chemistry, 2019, 67(41): 11454-11463 (doi: 10.1021/acs.jafc.9b05691).

32. Salles M.S.V., D’Abreu L.F., Júnior L.C.R., César M.C., Guimarres J.G.L., Segura J.G., Rodrigues C., Zanetti M.A., Pfrimer K., Netto A.S. Inclusion of sunflower oil in the bovine diet improves milk nutritional profile. Nutrients, 2019, 11(2): 2-15 (doi: 10.3390/nu11020481).

33. Katan T., Caballero-Solares A., Taylor R.G., Rise M.L., Parrish C.C. Effect of plant-based diets with varying ratios of $\omega 6$ to $\omega 3$ fatty acids on growth performance, tissue composition, fatty acid biosynthesis and lipid-related gene expression in Atlantic salmon (Salmo salar). Comparative Biochemistry and Physiology Part D: Genomics and Proteomics, 2019, 30: 290-304 (doi: 10.1016/j.cbd.2019.03.004).

34. Dong X.F., Liu S., Tong J.M. Comparative effect of dietary soybean oil, fish oil, and coconut oil on performance, egg quality and some blood parameters in laying hens. Poultry Science, 2018, 97(7): 2460-2472 (doi: 10.3382/ps/pey094).

\title{
ФНЦ Всероссийский научно-исследовательский и технологический институт птицеводства РАН, \\ Поступила в редакцию 19 сентября 2019 года
} 141311 Россия, Московская обл., г. Сергиев Посад, ул. Птицеградская, 10, e-mail: Vertiprakhov63@mail.ru $\bowtie$, Alena_fisinina@mail.ru, olga@vnitip.ru

Sel'skokhozyaistvennaya biologiya [Agricultural Biology], 2020, V. 55, № 4, pp. 726-737

\section{THE EXOCRINE PANCREATIC FUNCTION IN CHICKEN (Gallus gallus L.) FED DIETS SUPPLEMENTED WITH DIFFERENT VEGETABLE OILS}

\author{
V.G. Vertiprakhov, A.A. Grozina, V.I. Fisinin
}

Federal Scientific Center All-Russian Research and Technological Poultry Institute RAS, 10, ul. Ptitsegradskaya, Sergiev Posad, Moscow Province, 141311 Russia, e-mail Vertiprakhov63@mail.ru ( $\square$ corresponding author), Alena_fisinina@mail.ru,olga@vnitip.ru

ORCID:

Vertiprakhov V.G. orcid.org/0000-0002-3240-7636

Grozina A.A. orcid.org/0000-0001-9654-7710

Fisinin V.I. orcid.org/0000-0003-0081-6336 
Supported financially from a subprogram "Study of adaptation mechanisms of the digestive system of mammals and poultry to diets with various ingredients" of the Program for Basic Research (Resolution of the Presidium RAS No. 132 dated $07 / 05 / 2017$ )

\section{Abstract}

The efficiency of different vegetable oils in poultry nutrition is still a matter of interest for the theory and practice; numerous studies in broilers have evidenced that different oils can significantly affect the productive performance and metabolism. However, the mechanism of the influence of different oils on the exocrine pancreatic function is understudied. In our study on fistulated chicken the innovative data are presented for the analysis of the effects of different dietary lipid sources on the secretion and enzymatic activities of pancreatic juice. The study was performed in 2019 on three laying hens (Gallus gallus L., cross Hisex White) with chronic fistulae of main pancreatic duct inserted by the method of Ts.Zh. Batoev (2001). The physiological trials were performed by the method of periods (710 days per period): during the control period the basic feed (commercial compound feed for layers PK-1) was supplemented with sunflower oil; during period 1 with soybean oil; during period 2 rapeseed oil; during period 3 flaxseed oil. The pancreatic juice and blood were sampled throughout these periods. The secretion rate of pancreatic juice and enzymatic activities in it (amylase, lipase, total proteases TP, alkaline phosphatase AP) were determined by standard methods. The activities of amylase, lipase, alanine (ALT) and aspartate (AST) transaminases in blood serum were determined on analyzer ChemWell 2900 (T) (Awareness Technology, USA) with corresponding reagent kits by Human $\mathrm{GmbH}$, Germany; the activities of TP and AP and other biochemical indices in blood serum were determined on semi-automatic analyzer Sinnowa BS-3000P (SINNOWA Medical Science \& Technology Co., China) with BAPNA as the substrate (TP) and corresponding reagent kits by DIAKONVET, Russia (AP and all other indices). It was found that the activity of lipase in pancreatic juice can adjust to the dietary oil used. The significantly highest lipase activity was found with unrefined sunflower oil $\left(21345 \pm 652.8 \mu \mathrm{mol} \cdot \mathrm{1}^{-1} \cdot \mathrm{min}^{-1}, \mathrm{p}<0.05\right)$, together with the increases in the activity of amylase $\left(9254 \pm 440.3 \mathrm{mg} \cdot \mathrm{ml}^{-1} \cdot \mathrm{min}^{-1}, \mathrm{p}<0.05\right)$. The increases in lipolitic activity in the first few postprandial minutes (corresponding to complex-reflex phase of regulation of the pancreatic secretion) with sunflower and flaxseed oils evidenced that these oils are the most palatable for chicken while the increase in the activity of lipase in neurohumoral phase of regulation with rapeseed and soybean oils evidenced their higher nutritive value. The strong negative correlation $(r=-0.87$, $\mathrm{p}<0.05$ ) was also found between the activities of TP and AP in the pancreatic juice. The phosphatase-protease index, AP/TP ratio, is proposed as a significant physiological indicator of the adaptation of the digestive tract in poultry to the changes in diet composition. The most affected by oil type blood indices were the activities of TP, lipase, ALT, AST, and concentration of triglycerides. The dynamics of lipase activity in blood serum was similar to that in the pancreatic juice; the AP/TP ratio in serum was partially close to the values of this ratio in the pancreatic juice. The changes found in the exocrine pancreatic function in response to different dietary oils evidenced that the studies on the digestion should be continued for further optimization of the composition of commercial diets for poultry.

Keywords: exocrine pancreatic function, chickens, digestive enzymes in blood, sunflower oil, soybean oil, rapeseed oil, flaxseed oil. 